\title{
Microbiological Testing for the Proper Assessment of the Hygiene Status of Beef Carcasses
}

\author{
Anderson Carlos Camargo ${ }^{1}$, Marcus Vinícius Coutinho Cossi ${ }^{2}$, Wladimir Padilha da Silva ${ }^{3}$, \\ Luciano dos Santos Bersot ${ }^{4}{ }^{(0)}$, Mariza Landgraf ${ }^{5}$, József Baranyi $\left.{ }^{6}{ }^{(}\right)$, \\ Bernadette Dora Gombossy de Melo Franco ${ }^{5}$ and Nero Luís Augusto ${ }^{1, *}$
}

1 Universidade Federal de Viçosa, Departamento de Veterinária, Campus UFV, Viçosa 36570-900, MG, Brazil; anderson.c.camargo@hotmail.com

2 Universidade Federal de Uberlândia, Faculdade de Medicina Veterinária, Campus Umuarama, Uberlândia 38400-902, MG, Brazil; marcuscossi@yahoo.com.br

3 Universidade Federal de Pelotas, Departamento de Ciência e Tecnologia Agroindustrial, Campus Capão do Leão, Pelotas 96001-970, RS, Brazil; wladimir.padilha2011@gmail.com

4 Universidade Federal do Paraná, Departamento de Ciências Veterinárias, Rua Pioneiro, 2153, Palotina 85950-000, PR, Brazil; lucianobersot@gmail.com

5 Food Research Center, Universidade de São Paulo, Faculdade de Ciências Farmacêuticas, Departamento de Alimentos e Nutrição Experimental, Cidade Universitária, São Paulo 05508-080, SP, Brazil; landgraf@usp.br (M.L.), bfranco@usp.br (B.D.G.d.M.F.)

6 University of Debrecen, Institute of Nutrition, Böszörményi út 138, H-4032 Debrecen, Hungary; jozsef.baranyi@gmail.com

* Correspondence: nero@ufv.br; Tel.: +55-31-3899-1463; Fax: +55-31-3899-1457

Received: 30 January 2019; Accepted: 16 March 2019; Published: 19 March 2019

\begin{abstract}
Microbiological testing is an important quality management tool in the food industry. In this study, the hygiene status of beef carcasses sampled in eight Brazilian slaughterhouses was assessed by enumeration of different hygiene indicator microorganisms, and a model to establish potential associations among these counts was proposed. The carcasses $(n=464)$ were surface sampled at four slaughtering steps (step 1: Hide after bleeding; step 2: Carcass after hide removal; step 3: Carcass after evisceration; step 4: Carcass after end washing) and subjected to a counting of mesophilic aerobes (MA), Enterobacteriaceae (EB), total coliforms (TC), and Escherichia coli (EC) using Petrifilm ${ }^{\mathrm{TM}}$ plates. Among the sampled beef carcasses (step 4), 32 (6.9\%) and $71(15.3 \%)$ presented counts above the microbiological criteria established by (EC) No. 1441/2007 for MA and EB, respectively. Thus, indicating that improvements in slaughter hygiene and a review of process controls are demanded in some of the studied slaughterhouses. The log count differences of EC, TC, and EB from MA were considered as response variables as a function of the slaughtering steps. Differential log counts changed consistently with the steps. The measurements, including the patterns in their inherently random variability, were fairly predictable from steps 1 and 4 . The results indicated that differential $\log$ counts for TC and EC are not relevant, as their concentrations and random pattern can be inferred from counts of MA and EB. The proposed model can be used as a valuable tool for the design and adoption of feasible quality control programs in beef industries. The adoption of such a tool should have a positive contribution on consumers' health and enhance product quality.
\end{abstract}

Keywords: cattle slaughterhouses; hygiene monitoring; microbiological criteria; quality control program 


\section{Introduction}

The Brazilian beef industry is largely export oriented with 9.71 million tons of beef produced and 2.03 million tons destined to be exported in 2017 [1]. Brazil is currently the second largest beef producer worldwide, behind the USA, and the second largest beef exporter, behind India [1,2]. To keep this prominent position in the global market, the Brazilian beef industry and local inspection agencies rely on strict quality control measures and programs in compliance with national and international quality and safety regulations [3-5].

Quality management programs aim to prevent contaminations and ensure food safety. Good hygiene practices (GHP) are mainly focused on facilities, equipment, utensils, employee training, cleaning, sanitation, storage, distribution, and pest control [6], while the hazard analysis and critical control points (HACCP) focus on all steps of processing, through monitoring of critical points for contamination and allowing preventive procedures to avoid the hazard $[7,8]$. Such controls can be guided by microbiological criteria for foods that include safety parameters related to foodborne microbial pathogens and hygiene indicators, such as counts of mesophilic aerobic bacteria, coliforms and Enterobacteriaceae $[9,10]$. Thus, hygiene indicator microorganisms (HIM) are essential to indicating that GHP and HACCP programs are in place within the industry $[6,11-13]$.

Enumeration of HIM provides information regarding general contamination, incipient spoilage, or reduced shelf-life, i.e., utility of the product. The quantitative information provided by these tests can be very useful for trend analysis and verification of process control as microbiological populations at a certain processing step that surpass a reference value or a trend indicate that corrective measures are necessary, which may include improvement of hygiene conditions and a revision of quality management procedures $[6,9,14,15]$.

Self-control programs focus the entire production chain from initial steps to end products [15-17]. The microbiological data generated along the production chain are systematically analyzed, generating a valuable database on the prevalent occurrence of different types of indicator microorganisms [6]. Despite the additional cost for companies, generated databases are valuable for trend analyses as they reflect the contamination dynamics in the production chain, enabling enhancements in the control of the microbiological contamination and improving the quality and safety of the end products [6].

Despite having to meet the established criteria for HIM by many importing countries, primarily in the European Union (EU) [18], Brazilian regulation does not establish criteria for mesophilic aerobes and Enterobacteriaceae on beef carcasses for the domestic market so far. Consequently, these groups of microorganisms are hardly monitored in Brazilian beef carcasses since it involves additional costs, such as professional training and laboratorial analysis. The scientific literature on the microbiological status of Brazilian beef carcasses reports data on the prevalence of pathogens such as Shiga toxin producing Escherichia coli, Salmonella spp., and Listeria monocytogenes as well as others [19-23], but little has been reported on HIM. Thus, the objective of this study was to generate data on the hygiene status of beef carcasses sampled in selected Brazilian slaughterhouses inspected by the Brazilian Ministry of Agriculture, and use the microbiological data to propose a mathematical model to indicate potential associations among the populations of HIM. The end goal is to help the meat industry in the design of proper quality control programs.

\section{Materials and Methods}

\subsection{Selection of the Slaughterhouses}

A total of 8 cattle slaughterhouses subjected to the Brazilian inspection service of the Ministry of Agriculture were selected for the study. The slaughterhouses were located in 3 Brazilian states: Minas Gerais (Sl 01, Sl 02, and Sl 03), Paraná (Sl 04, Sl 05, and Sl 06), and Rio Grande do Sul (Sl 07 and Sl 08). The characteristics of the selected slaughterhouses are shown in Table 1. 
Table 1. Characteristics of the selected Brazilian slaughterhouses.

\begin{tabular}{ccccc}
\hline Slaughterhouse & Location $\left(\right.$ State) $^{\mathbf{1}}$ & Slaughter Rate & Employees & Export \\
\hline S1 01 & MG & $150-180 /$ day & 50 & Yes \\
S1 02 & MG & $90-100 /$ day & 25 & No \\
S1 03 & MG & $130-150 /$ day & 50 & Yes \\
S1 04 & PR & $600-650 /$ day & 40 & No \\
S1 05 & PR & $400-450 /$ day & 50 & No \\
S1 06 & PR & $200-250 /$ day & 50 & No \\
S1 07 & RS & $130-150 /$ day & 140 & No \\
S1 08 & RS & $600-650 /$ day & 700 & Yes \\
\hline
\end{tabular}

${ }^{1}$ MG, Minas Gerais; PR, Paraná; and RS, Rio Grande do Sul; ${ }^{2}$ slaughtering on 2 or 3 days a week; ${ }^{3}$ slaughtering on 1 or 2 days a week.

\subsection{Sampling}

At each visit to the slaughterhouses, 10 carcasses were randomly selected and the same carcass was sampled at 4 steps of the slaughtering process: (1) hide after bleeding, (2) carcass after hide removal, (3) carcass after evisceration, and (4) carcass after end washing. A total of 464 carcasses were sampled: Sl 01: 69, S1 02: 70, S1 03: 70, Sl 04: 25, Sl 05: 40, S1 06: 40, S1 07: 75, and S1 08: 75 carcasses.

Surface sampling was done according to the recommendations of the International Organization for Standardization 17604 [24] and EC 1441 [18]. For sampling at steps 1 and 2, four sterile square plastic templates of $100 \mathrm{~cm}^{2}$ were placed in the shoulder and chest areas of the animal (two templates each side, total: $400 \mathrm{~cm}^{2}$ ). The templates were placed in adjacent areas, avoiding sampling of the same site. After splitting the carcasses in 2, two templates of $100 \mathrm{~cm}^{2}$ were placed in each side (internal and external areas of the thoracic region, steps 3 and 4), completing $400 \mathrm{~cm}^{2}$. Each delimited area was swabbed with a sterile Hydrated-Sponge (3M Microbiology, St. Paul, MN, USA), moistened with $10 \mathrm{~mL}$ of sterile saline $(0.85 \% w / v)$ (Oxoid Ltd., Basingstoke, UK). The four sponges obtained at the same step $(1,2,3$, or 4$)$ were pooled in one sterile plastic bag $\left(\right.$ Whirl-Pak ${ }^{\circledR}$, Fort Atkinson, WI, USA), and kept at $4{ }^{\circ} \mathrm{C}$ until submitted to the microbiological tests (maximum $6 \mathrm{~h}$ ).

\subsection{Enumeration of Hygiene Indicator Microorganisms}

The bags with the four sponges were stomached with $160 \mathrm{~mL}$ of buffered peptone saline (Stomacher 400 Circulator, Seward Ltd, Worthing, UK) for $60 \mathrm{~s}$ and the liquid in the bags was subjected to ten-fold dilutions in sterile saline $0.85 \%(w / v)$. The dilutions were plated on Petrifilm ${ }^{\mathrm{TM}}$ plates $(3 \mathrm{M}$ Microbiology): Petrifilm ${ }^{\mathrm{TM}}$ AC for mesophilic aerobes (MA), Petrifilm ${ }^{\mathrm{TM}}$ EB for Enterobacteriaceae (EB), Petrifilm ${ }^{\mathrm{TM}} \mathrm{EC}$ for total coliforms (TC), and E. coli (EC), and incubated at $35^{\circ} \mathrm{C}$ for 24 to $48 \mathrm{~h}$. Plating procedures and counting of colonies were done according to the recommendations of the manufacturer. Results were expressed as $\log \mathrm{CFU} / \mathrm{cm}^{2}$.

\subsection{Statistical Analysis}

The log values of the mean bacterial populations at each sampling step of the 8 slaughterhouses were submitted to regression analysis to check potential trends at the tested steps. The differences (D) between the log counts of each $\mathrm{HIM}\left(\mathrm{D}_{\mathrm{EB}}, \mathrm{D}_{\mathrm{TC}}\right.$, and $\left.\mathrm{T}_{\mathrm{EC}}\right)$ and the total aerobic count (MA) for each sampling step were calculated whenever possible, and the resulting values were studied as a function of the location of the slaughterhouse (Brazilian state) and the slaughtering step, using linear regression and ANOVA. The significance level was fixed at $p<0.05$. Microsoft Excel and its statistical functions were used for these calculations.

\section{Results and Discussion}

During the cattle slaughtering and processing, contamination can occur via slaughter facility and carcasses handling. Based on these key procedures, regulations and guidelines are in place to ensure 
the quality and safety of the beef distributed to human consumption. In the present study, we accessed the hygiene status in different steps of cattle slaughtering and the quality of beef carcasses (after final washing) in Brazil. The mean populations of MA, EB, TC, and EC in the tested beef carcasses are shown in Table 2. As expected, samples taken at step 1 (hide after bleeding) presented significantly higher populations of the HIM than samples taken during the other three steps $(p<0.0001)$. At step 2 (after hide removal), the populations of all HIM were at least $1.5 \log \mathrm{CFU} / \mathrm{cm}^{2}$ lower than those observed in the samples taken at step 1. Other studies carried out in Brazilian slaughterhouses reported a similar trend $[22,25]$.

Table 2. Mean counts $\left(\log \mathrm{CFU} / \mathrm{cm}^{2} \pm \mathrm{SD}\right.$ ) of hygiene indicator microorganisms (HIM) in samples collected at four steps of the slaughtering process in eight Brazilian slaughterhouses.

\begin{tabular}{ccccc}
\hline \multirow{2}{*}{ HIM } & \multicolumn{4}{c}{ Slaughtering Step } \\
\cline { 2 - 5 } & $\mathbf{1}$ & $\mathbf{2}$ & $\mathbf{3}$ & $\mathbf{4}$ \\
\hline MA & $4.51 \pm 0.06^{\mathrm{a}}$ & $2.47 \pm 0.06^{\mathrm{c}}$ & $2.64 \pm 0.06^{\mathrm{c}}$ & $2.93 \pm 0.06^{\mathrm{b}}$ \\
EB & $3.27 \pm 0.06^{\mathrm{a}}$ & $1.79 \pm 0.08^{\mathrm{c}}$ & $2.20 \pm 0.07^{\mathrm{b}}$ & $2.11 \pm 0.07^{\mathrm{b}}$ \\
TC & $3.20 \pm 0.06^{\mathrm{a}}$ & $1.73 \pm 0.09^{\mathrm{c}}$ & $2.05 \pm 0.08^{\mathrm{b}}$ & $1.81 \pm 0.07^{\mathrm{bc}}$ \\
EC & $3.06 \pm 0.06^{\mathrm{a}}$ & $1.58 \pm 0.09^{\mathrm{bc}}$ & $1.89 \pm 0.08^{\mathrm{b}}$ & $1.53 \pm 0.08^{\mathrm{c}}$ \\
\hline
\end{tabular}

MA, mesophilic aerobes; EB, Enterobacteriaceae; TC, total coliforms; EC, Escherichia coli; slaughtering steps: (1) hide after bleeding; (2) after hide removal; (3) after evisceration; and (4) after end washing. For each microbial group, different letters indicate significant differences among slaughtering steps $(p<0.0001)$.

Evisceration played a significant role in carcass recontamination as populations of EB and TC in samples taken at step 3 were higher than in step $2(p<0.0001$, Table 2$)$. The populations at step 4 (after end washing) were significantly lower than at step $1(p<0.0001)$. However, populations at step 4 were higher than in step 2, which was similarly observed by Zweifel, et al. [26], suggesting that final washing was not enough to counterpart the contamination that occurred during evisceration.

When geographical locations (Brazilian states) are compared, samples collected in MG presented higher MA populations than samples from the two other states, in all steps (Table 3). The lowest populations of $\mathrm{EB}\left(0.8 \log \mathrm{CFU} / \mathrm{cm}^{2}\right)$ were observed in samples taken in PR at step 2, and the highest (3.6 log CFU $\left./ \mathrm{cm}^{2}\right)$ in RS at step 1. Samples from PR presented the lowest populations for EB, TC and EC, regardless the step of sampling. Despite the observed differences on microbial counts, it is important to highlight that all facilities were inspected based on same and identical guidelines determined by the Brazilian inspection service from the Ministry of Agriculture.

Results of ANOVA indicated that the populations of HIM decreased over processing (steps 1 to 4 , $p<0.005)$, regardless the geographical location of the slaughterhouse. Comparisons of the populations indicated that when the counts at step 1 were high, the populations remained high in the following steps suggesting that the hygiene status of animal skin prior to slaughtering may plays a role in carcasses contamination. Hide-to-carcasses microbial cross-contamination can occur under commercial conditions [27-30]. However, [Hauge, et al. [31]] suggested that higher loads of MA and EB found in dirty cattle hides does not impact the hygienic quality of the carcasses, resulting in carcasses with the same quality of those obtained from animals with clean hides. Anyway, it is important to clarify that carcasses contamination may be influenced by other factors, such as design of each facility and training of employees.

Enumeration of HIM on beef carcass has relevance because results correlate with the hygienic conditions during slaughtering $[8,32,33]$. Usually, microbiological limits are applied for meat, but some countries also stablish criteria for beef carcasses. In Brazil and in the USA, beef carcass safety is assessed based on detection of foodborne pathogens (such as Salmonella, Listeria monocytogenes, and pathogenic Escherichia coli), while counting of HIM is not mandatory [34,35]. However, in Europe, the (EC) No. 1441/2007 sets limits of MA and EB for cattle carcass after dressing (step 4 of the present study): $\mathrm{m}=3.5 \log \mathrm{CFU} / \mathrm{cm}^{2}$ and $\mathrm{M}=5.0 \log \mathrm{CFU} / \mathrm{cm}^{2}$ for $\mathrm{MA}$, and $\mathrm{m}=1.5 \log \mathrm{CFU} / \mathrm{cm}^{2}$ and $\mathrm{M}=$ $2.5 \log \mathrm{CFU} / \mathrm{cm}^{2}$ for EB $[5,18]$. In the present study, not all the evaluated beef carcasses in step 4 were 
within the microbial criteria established by (EC) No. 1441/2007 for MA and EB. As expected, most of the samples with counts above the European criteria were obtained from MG state (Table 4).

Table 3. Mean counts ( $\left.\log \mathrm{CFU} / \mathrm{cm}^{2} \pm \mathrm{SD}\right)$ of hygiene indicator microorganisms (HIM) in samples collected at four steps of the slaughtering process, in slaughterhouses located in the states of Minas Gerais (MG), Paraná (PR) and Rio Grande do Sul (RS), Brazil.

\begin{tabular}{|c|c|c|c|c|c|}
\hline \multirow{2}{*}{ HIM } & \multirow{2}{*}{ State } & \multicolumn{4}{|c|}{ Slaughtering Step } \\
\hline & & 1 & 2 & 3 & 4 \\
\hline \multirow[t]{3}{*}{ MA } & MG & $4.66 \pm 0.08^{\mathrm{Aa}}$ & $2.85 \pm 0.07^{\mathrm{Ad}}$ & $3.30 \pm 0.09 \mathrm{Ac}$ & $3.8 \pm 0.09 \mathrm{Ab}$ \\
\hline & PR & $4.34 \pm 0.11^{\mathrm{Ba}}$ & $2.43 \pm 0.09 \mathrm{Bb}$ & $2.03 \pm 0.12^{\mathrm{Bc}}$ & $2.46 \pm 0.12^{\mathrm{Bb}}$ \\
\hline & RS & $4.42 \pm 0.09 \mathrm{ABa}$ & $2.14 \pm 0.07 \mathrm{Cb}$ & $2.37 \pm 0.09^{\mathrm{Bb}}$ & $2.21 \pm 0.1^{\mathrm{Bb}}$ \\
\hline \multirow[t]{3}{*}{ EB } & MG & $3.37 \pm 0.08^{\mathrm{Aa}}$ & $1.89 \pm 0.1^{\mathrm{Ac}}$ & $2.24 \pm 0.11^{\mathrm{Abc}}$ & $2.46 \pm 0.08^{\mathrm{Ab}}$ \\
\hline & PR & $2.56 \pm 0.11^{\mathrm{Ba}}$ & $0.84 \pm 0.17^{\mathrm{Bc}}$ & $1.45 \pm 0.23^{\mathrm{Bb}}$ & $1.02 \pm 0.15^{\mathrm{Cbc}}$ \\
\hline & RS & $3.61 \pm 0.09 \mathrm{Aa}$ & $2.01 \pm 0.1 \mathrm{Ac}$ & $2.37 \pm 0.12 \mathrm{Ab}$ & $2.09 \pm 0.1^{\mathrm{Bbc}}$ \\
\hline \multirow[t]{3}{*}{$\mathrm{TC}$} & MG & $3.25 \pm 0.1 \mathrm{Aa}$ & $1.77 \pm 0.13^{\mathrm{ABb}}$ & $2.05 \pm 0.13 \mathrm{Ab}$ & $2.0 \pm 0.7 \mathrm{Ab}$ \\
\hline & PR & $2.63 \pm 0.13^{\mathrm{Ba}}$ & $1.22 \pm 0.22^{\mathrm{Bb}}$ & $0.95 \pm 0.25^{\mathrm{Bb}}$ & $0.85 \pm 0.15^{\mathrm{Bb}}$ \\
\hline & RS & $3.45 \pm 0.1 \mathrm{Aa}$ & $1.84 \pm 0.12 \mathrm{Ac}$ & $2.34 \pm 0.13^{\mathrm{Ab}}$ & $1.86 \pm 0.08 \mathrm{Ac}$ \\
\hline \multirow[t]{3}{*}{$\mathrm{EC}$} & MG & $3.14 \pm 0.1 \mathrm{Aa}$ & $1.72 \pm 0.12^{\mathrm{Ab}}$ & $1.91 \pm 0.15^{\mathrm{Ab}}$ & $1.66 \pm 0.1^{\mathrm{Ab}}$ \\
\hline & PR & $2.46 \pm 0.13^{\mathrm{Ba}}$ & $0.93 \pm 0.2^{\mathrm{Bb}}$ & $0.86 \pm 0.28^{\mathrm{Bb}}$ & $0.52 \pm 0.24^{\mathrm{Bb}}$ \\
\hline & RS & $3.36 \pm 0.1^{\mathrm{Aa}}$ & $1.66 \pm 0.1^{\mathrm{Ac}}$ & $2.12 \pm 0.13^{\mathrm{Ab}}$ & $1.55 \pm 0.08^{\mathrm{Ac}}$ \\
\hline
\end{tabular}

MA, mesophilic aerobes; EB, Enterobacteriaceae; TC, total coliforms; EC, Escherichia coli; slaughtering steps: (1) hide after bleeding; (2) after hide removal; (3) after evisceration; and (4) after end washing. MG, Minas Gerais; PR, Paraná; and RS, Rio Grande do Sul. For each hygiene indicator group, different upper-case letters indicate significant differences among states $(p<0.05)$, and different lower-case letters indicate significant differences among slaughtering steps $(p<0.005)$.

Table 4. Number of carcasses after final washing (step 4) with counts above the criteria established by (EC) No. 1441/2007 for mesophilic aerobes $\left(\mathrm{M}=5 \log \mathrm{cfu} / \mathrm{cm}^{2}\right)$ and Enterobacteriaceae $\left(\mathrm{M}=2.5 \log \mathrm{cfu} / \mathrm{cm}^{2}\right)$.

\begin{tabular}{cccc}
\hline State & $\boldsymbol{n}$ & Mesophilic Aerobes & Enterobacteriaceae \\
\hline MG & 209 & $30(14.4 \%)$ & $61(29.2 \%)$ \\
PR & 105 & $2(1.9 \%)$ & $1(1.0 \%)$ \\
RS & 150 & $0(0.0 \%)$ & $9(6.0 \%)$ \\
Total & 464 & $32(6.9 \%)$ & $71(15.3 \%)$ \\
\hline
\end{tabular}

MG, Minas Gerais; PR, Paraná; and RS, Rio Grande do Sul.

The hide, hair, hooves, and gastrointestinal tract are the main sources of microorganism in live animals [10,32,36,37]. Carcasses that are not subjected to contact with the hide during skinning or with the fecal content during evisceration typically present low microbial contamination [27]. Bacterial loads on carcasses can be reduced by spraying with organic acids or other approved antimicrobial compounds, but these compounds, routinely used in certain countries, are not allowed in Brazil [37-39].

Figure 1 shows the correlation indexes calculated for the microbial counts $\left(\log \mathrm{CFU} / \mathrm{cm}^{2}\right)$ of MA, EB, TC, and EC in the carcasses obtained at different steps of slaughtering. The correlation indexes ranged from 0.10 for TC to 0.43 for MA when steps 1 and 2 are compared, and from 0.29 for EC to 0.42 for EB when steps 2 and 3 are compared. The indexes between the populations in steps 3 and 4 ranged from 0.23 for EB to 0.44 for MA. These indexes were all significant $(p<0.05)$. Similar trends were observed for samples collected in the three states, though with varying confidence measures (Supplementary Figure S1-3). Such correlation indexes can be useful to find patterns in the contamination levels at different steps of the food processing chain, helping to select the key steps that require extra attention and rigorous control. Although the evaluation of the microbiological criteria of final products remains a requirement, such patterns may be very helpful in the development of self-control plans, making the contamination monitoring more realistic $[6,8]$. 

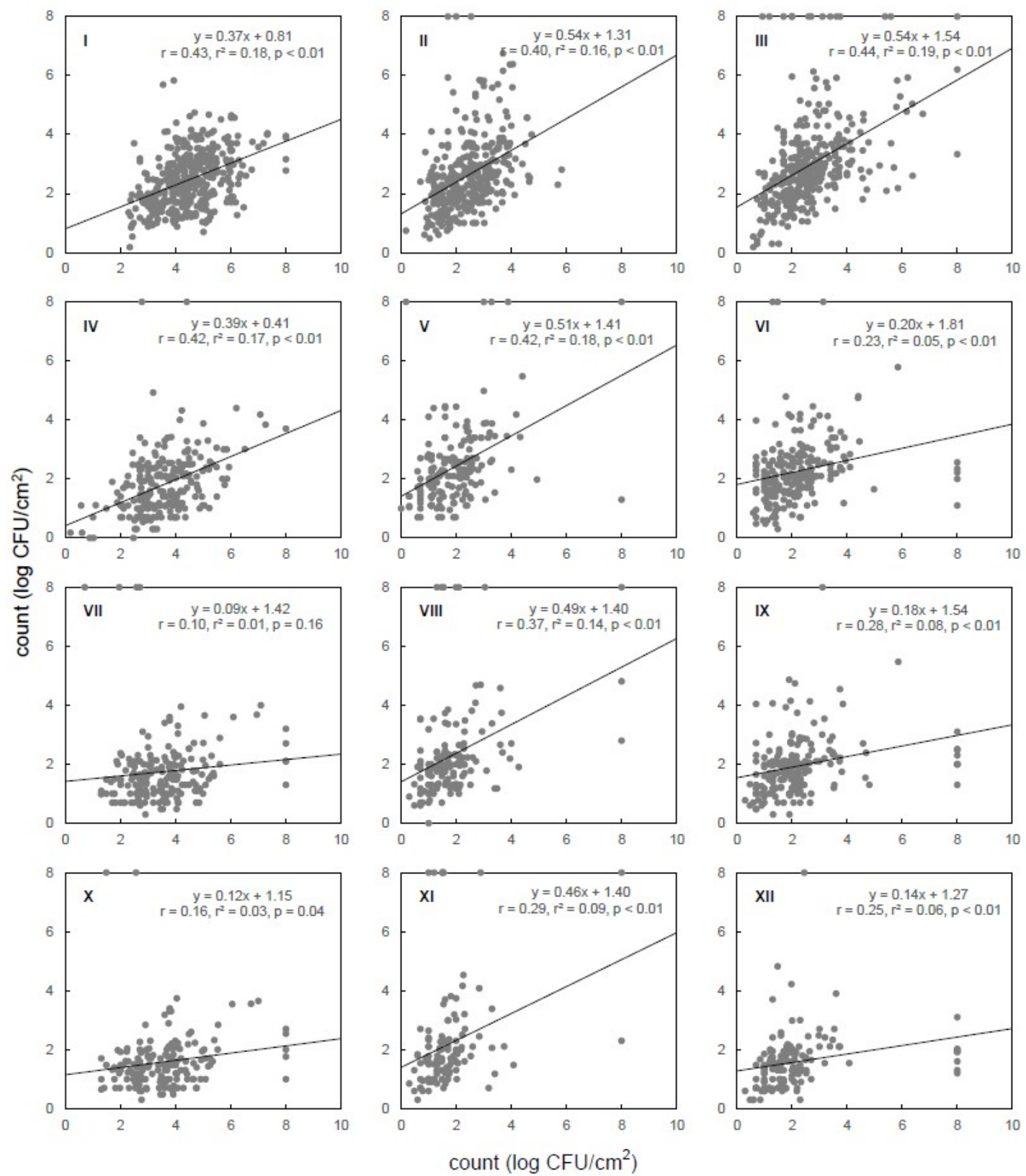

Figure 1. Dispersion of microbial counts $\left(\log \mathrm{CFU} / \mathrm{cm}^{2}\right)$ of mesophilic aerobes (I, II, III), Enterobacteriaceae (IV, V, VI), total coliforms (VII, VIII, IX), and Escherichia coli (X, XI, XII) from bovine carcasses obtained in different steps of slaughtering (' $y$ ' vs. ' $x$ '): 'after hide removal (step 1)' vs. 'hide after bleeding (step 2)' (I, IV, VII, X), 'after evisceration (step 3)' vs. 'after hide removal (step 1)' (II, $\mathrm{V}, \mathrm{VIII}, \mathrm{XI}$ ), and 'after washing (step 4)' vs. 'after evisceration (step 3)' (III, VI, IX, XII). In each graph, r is the correlation coefficient, $\mathrm{r}^{2}$ is the coefficient of determination, and $\mathrm{p}$ is the level of significance.

Denoting the differences between the log counts of a given HIM from the correspondent MA by $\mathrm{D}_{\mathrm{EB}}, \mathrm{D}_{\mathrm{TC}}$, and $\mathrm{D}_{\mathrm{EC}}$, a linear trend can be established $(p<0.05)$ along the slaughtering steps:

$$
\mathrm{D}_{\mathrm{HIM}}=a_{H I M} \cdot \text { step }+b_{H I M}+\varepsilon
$$

where the slope $a_{H I M}$ depends on the state and the $\varepsilon$ random component is normally distributed with a deviation $0.6<\sigma<0.8$ (Figure 2). The same linear pattern proved to be valid for the differences for $\mathrm{D}_{\mathrm{TC}}$ and $\mathrm{D}_{\mathrm{EB}}$ (Figure 3). The averages of the $\mathrm{D}_{\mathrm{HIM}}$ values follow a monotonic trend with the steps, as a function of the state, and these values at the edges (steps 1 and 4) determine the values at steps 2 
and 3 with acceptable accuracy. As a consequence, the intermediate steps could be spared, since they (together with the nature of their randomness) can be described by the linear model based on steps 1 and 4 only (Figure 3).
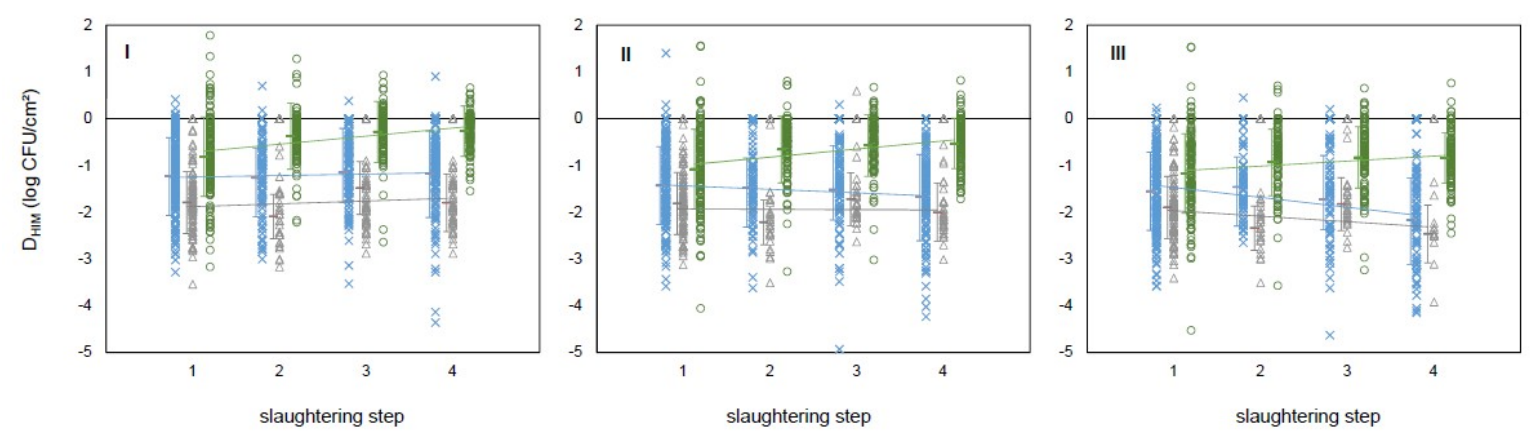

Figure 2. Differences between the microbial counts $\left(\log \mathrm{CFU} / \mathrm{cm}^{2}\right)$ of $\mathrm{MA}$ and a given hygiene indicator microorganism ( $\mathrm{D}_{\mathrm{HIM}}$; I: Enterobacteriaceae; II: Total coliforms; and III: Escherichia coli) as a function of the slaughtering step (step 1: Hide after bleeding; step 2: Carcass after hide removal; step 3: Carcass after evisceration; and step 4: Carcass after end washing), and the state of sample collection (blue cross: MG; gray triangle: PR; green circle: RS). The slopes are state-dependent and significantly different from zero $(p<0.05)$ while the error around the linear trend can well be approximated by the normal distribution, with fairly constant deviation (see the error bars around the respective averages).

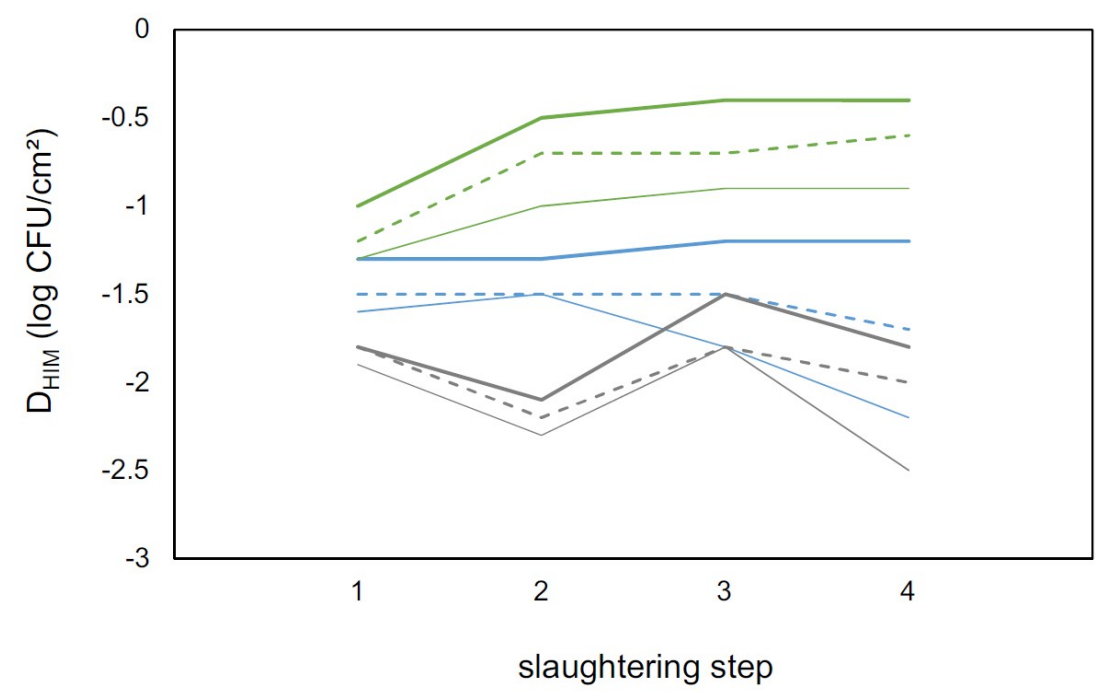

Figure 3. Differences between the microbial counts $\left(\log \mathrm{CFU} / \mathrm{cm}^{2}\right)$ of $\mathrm{MA}$ and a given hygiene indicator microorganism ( $\mathrm{D}_{\mathrm{HIM}}$; Enterobacteriaceae: Dot lines; Total coliforms; dash lines; and Escherichia coli: Continuous line) in different steps of slaughtering (step 1: Hide after bleeding; step 2: After hide removal; step 3: After evisceration; and step 4: After end washing) in eight slaughterhouses located in three Brazilian states (Minas Gerais: Blue lines; Paraná: Grey lines; and Rio Grande do Sul: Green lines).

For validation, $\mathrm{D}_{\mathrm{EB}}$ values were modelled by the above linear function (1) using the data from steps 1 and 4 only, then the mean and distribution of $D_{\mathrm{EB}}$ at steps 2 and 3 were inferred, assuming normal distribution and deviation, which was the standard error of fitting. The results are summarized in Figure 4, where columns represent the histograms created from the $\mathrm{D}_{\mathrm{EB}}$ observations. The plots are comparing not only predicted and observed $\mathrm{D}_{\mathrm{EB}}$ values, but also their standard deviation. The reason why $\mathrm{D}_{\mathrm{EB}}$ was chosen among the HIM as a reference is that the concentration of EB is generally still high enough that the 'not-detected' results do not increase the uncertainty in the data. If the measurements have the same error at low concentrations too, EC would have been a better candidate as the counts of EC and MA encompass the other two (so the interpolation, which is a more robust operation then 
extrapolation, would be ensured per se). However, analogous trials with the data suggest that $\mathrm{D}_{\mathrm{EB}}$ is a better choice for modelling than the other two and the $\mathrm{D}_{\mathrm{EB}}$ results at steps 2 and 3 can be inferred from the respective data at steps 1 and 4 within less than $1 \log$-unit $\left(0.6-0.8 \log \mathrm{CFU} / \mathrm{cm}^{2}\right)$ error. The source of error is the inherent variability of the system, shown by the results of replicated measurements. It is likely that the counts of EC and TC can also be inferred from the MA and EB results, as the $\mathrm{D}_{\mathrm{TC}}$ and $\mathrm{D}_{\mathrm{EC}}$ look linear depending on the steps, similarly to $\mathrm{D}_{\mathrm{EB}}$. However, this cannot be unambiguously confirmed due to the bigger errors in the measurements at lower concentrations.
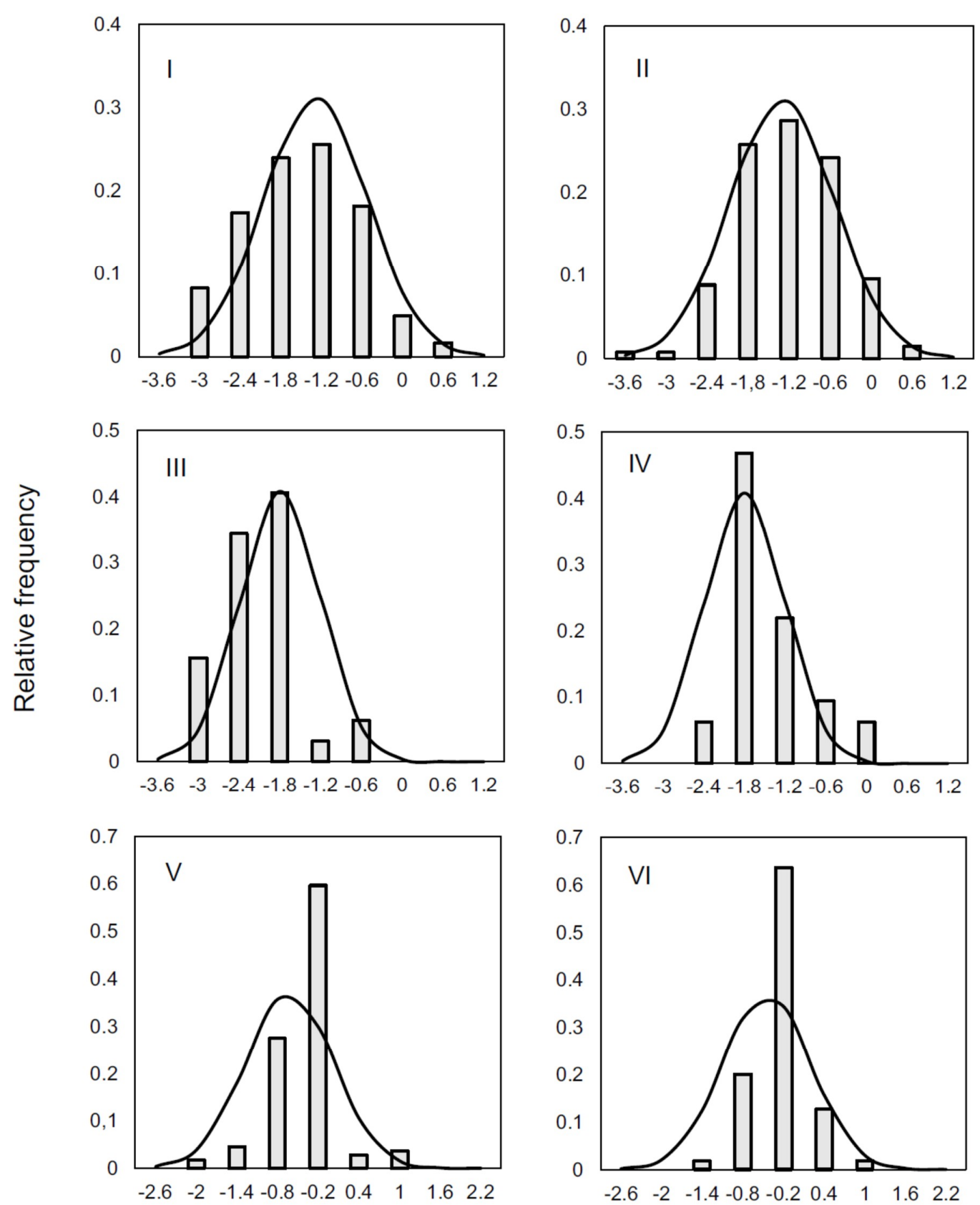

$\mathrm{D}_{\mathrm{EB}}$

$\mathrm{D}_{\mathrm{EB}}$

Figure 4. Distribution of $D_{\mathrm{EB}}$ values at steps 2 (left) and 3 (right), predicted from $\mathrm{D}_{\mathrm{EB}}$ data at steps 1 and 4. Minas Gerais: I and II; Paraná: III and IV; and Rio Grande do Sul: V and VI. 
Several factors can affect the microbial counts, as microorganisms are not equally distributed over the carcass. In addition, contamination levels can vary according to several factors such as the day of sampling, sample collection procedure, and analytical method $[8,27,40]$. Thus, beef carcasses quality assessment requires careful interpretation. Despite the requirement for microbiological analysis in beef carcasses only after final washing (step 4), the systematic analysis of microbiological indicators and pathogens along cattle slaughtering and beef processing is important to provide historical data on the hygiene during processing and check for compliance with holistic quality control programs based on GHP and HACCP [17,34].

Among the sampled beef carcasses, $32(6.9 \%)$ and $71(15.3 \%)$ presented counts above the microbiological criteria established by (EC) No. 1441/2007 for MA and EB, respectively. Most of them were obtained in facilities located in the MG state (Table 4). These results indicate that improvements in slaughter hygiene and a review of process controls are demanded. The monitoring preconized by self-control programs implies costs for the companies. However, identification of specific hygienic weak points along the slaughter process is necessary to improve the quality of final products, and it only can be achieved through microbiological data $[6,8,41]$. Considering that the EU has set MA and EB as microbiological criteria for beef carcasses $[5,18]$, the counts of these two HIM were selected to design a mathematical model capable of predicting the populations of CT and EC. The proposed model also indicated that the microbiological data obtained at slaughtering steps 1 and 4 were enough to infer the contamination level in intermediary steps 2 and 3, helping the beef industry to develop more objective and feasible quality control programs. Adoption of such programs should have a positive contribution on consumers' health, enhancing product quality, and enabling companies to maintain and enlarge their markets based on the recognition of their rigorous quality management initiatives.

Supplementary Materials: Supplementary materials can be found at http:/ / www.mdpi.com/2076-2607/7/3/ 86/s1.

Author Contributions: B.D.G.d.M.F., L.A.N., W.P.S., L.S.B., and M.L. designed the study. A.C.C. and M.V.C.C. collected samples and conducted laboratory work. L.A.N. and J.B. conducted data analysis. A.C.C., L.A.N., B.D.G.d.M.F., and J.B. wrote the manuscript. All authors reviewed and agreed with the submitted version of the manuscript.

Funding: CNPq, CAPES (financial code 001), FAPEMIG and FAPESP (process 2013/07914-8).

Conflicts of Interest: The authors declare no conflict of interest.

\section{References}

1. ABIEC. Perfil da pecuária no Brasil—Profile of Brazilian Cattle Production. Available online: http://abiec. siteoficial.ws/images/upload/sumario-pt-010217.pdf (accessed on 11 January 2019).

2. Brasil. Ministério da Indústria, Comércio Exterior e Serviços. Available online: http:/ /www.mdic.gov.br/ (accessed on 11 January 2019).

3. Neeliah, S.A.; Neeliah, H.; Goburdhun, D. Assessing the relevance of EU SPS measures to the food export sector: Evidence from a developing agro-food exporting country. Food Policy 2013, 41, 53-62. [CrossRef]

4. Zach, L.; Doyle, M.E.; Bier, V.; Czuprynski, C. Systems and governance in food import safety: A U.S. perspective. Food Control 2012, 27, 153-162. [CrossRef]

5. Lafisca, A.; Almeida, M.V.; Pinto, P.S.A.; Nero, L.A. European food safety requirements leading to the development of Brazilian cattle sanity and beef safety. Eur. Food Feed Law Rev. 2013, 8, $259-269$.

6. Peran i Sala, R.M.; Cedeño de Balabarca, V.; Etoundi, J.M.; Odame-Darkwah, J.; Oppong-Otoo, J.; Tossougbo Hinson, D.C.; Wouafo, M. Establishment of good hygiene practice-based microbiological criteria in food industries: Guidelines using an example for meat preparations. Food Control 2015, 58, 7-11. [CrossRef]

7. Kafetzopoulos, D.P.; Psomas, E.L.; Kafetzopoulos, P.D. Measuring the effectiveness of the HACCP Food Safety Management System. Food Control 2013, 33, 505-513. [CrossRef] 
8. Alvseike, O.; Røssvoll, E.; Røtterud, O.-J.; Nesbakken, T.; Skjerve, E.; Prieto, M.; Sandberg, M.; Johannessen, G.; Økland, M.; Urdahl, A.M.; et al. Slaughter hygiene in European cattle and sheep abattoirs assessed by microbiological testing and Hygiene Performance Rating. Food Control 2019, 101, $233-240$. [CrossRef]

9. ICMSF. Microorganisms in Foods 8: Use of Data for Assessing Process Control and Product Acceptance; International Commission on Microbiological Specifications for Foods: New York, NY, USA, 2011; Volume 8, p. 400.

10. Ray, B.; Bhunia, A. Fundamental Food Microbiology; CRC Press: Boca Raton, FL, USA, 2007.

11. Luning, P.A.; Jacxsens, L.; Rovira, J.; Osés, S.M.; Uyttendaele, M.; Marcelis, W.J. A concurrent diagnosis of microbiological food safety output and food safety management system performance: Cases from meat processing industries. Food Control 2011, 22, 555-565. [CrossRef]

12. Buncic, S.; Nychas, G.J.; Lee, M.R.F.; Koutsoumanis, K.; Hébraud, M.; Desvaux, M.; Chorianopoulos, N.; Bolton, D.; Blagojevic, B.; Antic, D. Microbial pathogen control in the beef chain: Recent research advances. Meat Sci. 2014, 97, 288-297. [CrossRef] [PubMed]

13. Barco, L.; Belluco, S.; Roccato, A.; Ricci, A. A systematic review of studies on Escherichia coli and Enterobacteriaceae on beef carcasses at the slaughterhouse. Int. J. Food Microbiol. 2015, 207, 30-39. [CrossRef]

14. Brown, M.H.; Gill, C.O.; Hollingsworth, J.; Nickelson, R.; Seward, S.; Sheridan, J.J.; Stevenson, T.; Sumner, J.L.; Theno, D.M.; Usborne, W.R.; et al. The role of microbiological testing in systems for assuring the safety of beef. Int. J. Food Microbiol. 2000, 62, 7-16. [CrossRef]

15. Raspor, P. Total food chain safety: How good practices can contribute? Trends Food Sci. Technol. 2008, 19, 405-412. [CrossRef]

16. Brasil. Circular N ${ }^{\circ}$ 175/2005/CGPE/DIPOA—Procedimentos de Verificação dos Programas de Autocontrole. In MAPA; MAPA: Brasília, Brazil, 2005.

17. Wilhelm, B.; Rajić, A.; Greig, J.D.; Waddell, L.; Harris, J. The effect of hazard analysis critical control point programs on microbial contamination of carcasses in abattoirs: A systematic review of published data. Foodborne Pathog. Dis. 2011, 8, 949-960. [CrossRef] [PubMed]

18. EU. Commission Regulation (EC) No 1441/2007 amending Regulation (EC) No 2073/2005 on microbiological criteria for foodstuffs. Eur. Union Off. J. Eur. Union 2007, 332, 12-29.

19. Camargo, A.C.; Lafisca, A.; Cossi, M.V.C.; Lanna, F.G.P.A.; Dias, M.R.; Pinto, P.S.A.; Nero, L.A. Low occurrence of Listeria monocytogenes on bovine hides and carcasses in Minas Gerais state, Brazil: Molecular characterization and antimicrobial resistance. J. Food Prot. 2014, 77, 1148-1152. [CrossRef] [PubMed]

20. Cossi, M.V.C.; Burin, R.C.K.; Camargo, A.C.; Dias, M.R.; Lanna, F.G.P.A.; Pinto, P.S.A.; Nero, L.A. Low occurrence of Salmonella in the beef processing chain from Minas Gerais state, Brazil: From bovine hides to end cuts. Food Control 2014, 40, 320-323. [CrossRef]

21. Iglesias, M.A.; Kroning, I.S.; Decol, L.T.; Franco, B.D.G.M.; Silva, W.P. Occurrence and phenotypic and molecular characterization of Listeria monocytogenes and Salmonella spp. in slaughterhouses in southern Brazil. Food Res. Int. 2017, 100, 96-101. [CrossRef]

22. Loiko, M.R.; Paula, C.M.D.; Langone, A.C.J.; Rodrigues, R.Q.; Cibulski, S.; Rodrigues, R.O.; Camargo, A.C.; Nero, L.A.; Mayer, F.Q.; Tondo, E.C. Genotypic and antimicrobial characterization of pathogenic bacteria at different stages of cattle slaughtering in southern Brazil. Meat Sci. 2016, 116, 193-200. [CrossRef] [PubMed]

23. Farah, S.M.S.S.; Souza, E.M.; Pedrosa, F.O.; Irino, K.; Silva, L.R.; Rigo, L.U.; Steffens, M.B.R.; Pigatto, C.P.; Fadel-Picheth, C.M.T. Phenotypic and genotypic traits of Shiga toxin-producing Escherichia coli strains isolated from beef cattle from Paraná State, southern Brazil. Lett. Appl. Microbiol. 2007, 44, 607-612. [CrossRef]

24. ISO. ISO 17604-Microbiology of the Food Chain—Carcass Sampling for Microbiological Analysis; International Organization for Standardization: Geneva, Switzerland, 2015.

25. Matos, A.V.R.; Nunes, L.B.S.; Vianna, C.; Spina, T.L.B.; Zuim, C.V.; Possebon, F.S.; Xavier, D.M.; Ferraz, M.C.; Pinto, J.P.A.N. Listeria monocytogenes, E. coli O157, Salmonella spp. e microrganismos indicadores em carcaças bovinas para exportação. Arquivo Brasileiro de Medicina Veterinária e Zootecnia 2013, 65, 981-988. [CrossRef]

26. Zweifel, C.; Capek, M.; Stephan, R. Microbiological contamination of cattle carcasses at different stages of slaughter in two abattoirs. Meat Sci. 2014, 98, 198-202. [CrossRef] [PubMed]

27. Antic, D.; Blagojevic, B.; Ducic, M.; Nastasijevic, I.; Mitrovic, R.; Buncic, S. Distribution of microflora on cattle hides and its transmission to meat via direct contact. Food Control 2010, 21, 1025-1029. [CrossRef] 
28. McEvoy, J.M.; Doherty, A.M.; Finnerty, M.; Sheridan, J.J.; McGuire, L.; Blair, I.S.; McDowell, D.A.; Harrington, D. The relationship between hide cleanliness and bacterial numbers on beef carcasses at a commercial abattoir. Lett. Appl. Microbiol. 2000, 30, 390-395. [CrossRef]

29. Blagojevic, B.; Antic, D.; Ducic, M.; Buncic, S. Ratio between carcass-and skin-microflora as an abattoir process hygiene indicator. Food Control 2011, 22, 186-190. [CrossRef]

30. Hauge, S.J.; Nafstad, O.; Røtterud, O.-J.; Nesbakken, T. The hygienic impact of categorisation of cattle by hide cleanliness in the abattoir. Food Control 2012, 27, 100-107. [CrossRef]

31. Hauge, S.J.; Nesbakken, T.; Moen, B.; Røtterud, O.-J.; Dommersnes, S.; Nesteng, O.; Østensvik, Ø.; Alvseike, O. The significance of clean and dirty animals for bacterial dynamics along the beef chain. Int. J. Food Microbiol. 2015, 214, 70-76. [CrossRef]

32. Serraino, A.; Bardasi, L.; Riu, R.; Pizzamiglio, V.; Liuzzo, G.; Galletti, G.; Giacometti, F.; Merialdi, G. Visual evaluation of cattle cleanliness and correlation to carcass microbial contamination during slaughtering. Meat Sci. 2012, 90, 502-506. [CrossRef]

33. Tergney, A.; Bolton, D.J. Validation studies on an online monitoring system for reducing faecal and microbial contamination on beef carcasses. Food Control 2006, 17, 378-382. [CrossRef]

34. Brasil. Resolução-RDC 12 de 2 de janeiro: Regulamento técnico sobre os Padrões microbiológicos para alimentos. Diário Oficial da União 2001. Available online: http:/ / portal.anvisa.gov.br / documents/33880/ 2568070/RDC_12_2001.pdf/15ffddf6-3767-4527-bfac-740a0400829b (accessed on 16 March 2019).

35. FSIS (Ed.) Guidance for Minimizing the Risk of Escherichia coli O157:H7 and Salmonella in Beef Slaughter Operations; USDA: Washington, DC, USA, 2002; p. 32.

36. Bell, R.G. Distribution and sources of microbial contamination on beef carcasses. J. Appl. Microbiol. 1997, 82, 292-300. [CrossRef]

37. Loretz, M.; Stephan, R.; Zweifel, C. Antibacterial activity of decontamination treatments for cattle hides and beef carcasses. Food Control 2011, 22, 347-359. [CrossRef]

38. Koohmaraie, M.; Arthur, T.M.; Bosilevac, J.M.; Guerini, M.; Shackelford, S.D.; Wheeler, T.L. Post-harvest interventions to reduce/eliminate pathogens in beef. Meat Sci. 2005, 71, 79-91. [CrossRef]

39. Burin, R.C.K.; Silva, A.; Nero, L.A. Influence of lactic acid and acetic acid on Salmonella spp. growth and expression of acid tolerance-related genes. Food Res. Int. 2014, 64, 726-732. [CrossRef] [PubMed]

40. Røssvoll, E.; Hauge, S.J.; Skjerve, E.; Johannessen, G.; Økland, M.; Røtterud, O.-J.; Nesbakken, T.; Alvseike, O. Experimental evaluation of performance of sampling techniques for microbiological quantification on carcass surfaces. Food Prot. Trends 2017, 37, 419-429.

41. Milios, K.T.; Drosinos, E.H.; Zoiopoulos, P.E. Food safety management system validation and verification in meat industry: Carcass sampling methods for microbiological hygiene criteria-A review. Food Control 2014, 43, 74-81. [CrossRef]

(c) 2019 by the authors. Licensee MDPI, Basel, Switzerland. This article is an open access article distributed under the terms and conditions of the Creative Commons Attribution (CC BY) license (http://creativecommons.org/licenses/by/4.0/). 